\title{
Shortness of breath and chest discomfort in a young woman: panic disorder is not always a case
}

\author{
Aibek E Mirrakhimov, Aram Barbaryan, Alaa Ali, Erwin Velasquez Kho
}

Department of Internal Medicine, Saint Joseph Hospital, Chicago, Illinois, USA

\section{Correspondence to} Dr Aibek E Mirrakhimov, amirrakhimov1@gmail.com
To cite: Mirrakhimov AE Barbaryan A, Ali A, et al. BMJ Case Reports Published online: 6 December 2012 doi:10.1136/bcr-2012007728

\section{DESCRIPTION}

A 27-year-old, non-obese, non-smoker Caucasian woman with no medical history came to the emergency department, because of vague chest discomfort, shortness of breath and palpitations. Family history was significant only for lung cancer in her father at age 72 . ECG showed sinus tachycardia with a rate of $112 / \mathrm{min}$; chest $\mathrm{x}$-ray did not show any evidence of pulmonary or chest pathology. Troponins came back negative. The patient denied using medications and recreational drugs. The patient was presumed to have a panic attack and clonazepam was administered, with resolution of her symptoms within $1 \mathrm{~h}$.

Two weeks later the patient was hospitalised, because of chest pain, shortness of breath and lightheadedness. D-dimers came elevated, and CT scan of the chest with contrast showed filling defects in the main posteromedial basal segmental branch of the left lower lobe pulmonary artery and posterior

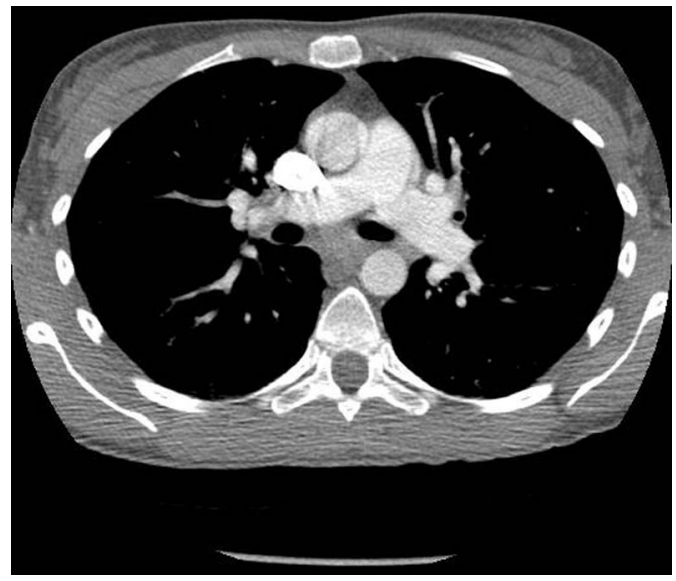

Figure $1 \mathrm{CT}$ angiography of the chest showing bilateral filling defects in the circulation of pulmonary arteries. basal segmental branch of the right lower lobe pulmonary artery. The patient was treated with low molecular weight heparin, with a switch to oral warfarin. Lower extremity Doppler ultrasound did not detect any evidence of thrombosis. After a thorough laboratory work-up, the patient was found to have anticardiolipin antibodies, with a confirmation 3 months later. The patient agreed to use warfarin indefinitely (figure 1).

Panic disorder usually presents in a young woman and may mimic diseases with a more ominous prognosis. ${ }^{1}$ Antiphospholipid syndrome is notorious for a propensity for clotting and is considered to be a risk factor for pulmonary embolism and pulmonary disorders. ${ }^{2}$

\section{Learning points}

- Panic disorder may mimic a disease with more ominous prognosis, due to non-specific symptomatology.

- The clinicians should have a low threshold for pursuing a further work-up for pulmonary embolism in young patients presenting with chest discomfort, anxiety and shortness of breath.

Competing interests None.

Patient consent Obtained.

\section{REFERENCES}

Roy-Byrne PP, Craske MG, Stein MB. Panic disorder. Lancet 2006;368:1023-32.

2 Ford HJ, Roubey RA. Pulmonary manifestations of the antiphospholipid antibody syndrome. Clin Chest Med 2010;31:537-45

Copyright 2012 BMJ Publishing Group. All rights reserved. For permission to reuse any of this content visit http://group.bmj.com/group/rights-licensing/permissions.

BMJ Case Report Fellows may re-use this article for personal use and teaching without any further permission.

Become a Fellow of BMJ Case Reports today and you can:

- Submit as many cases as you like

- Enjoy fast sympathetic peer review and rapid publication of accepted articles

- Access all the published articles

- Re-use any of the published material for personal use and teaching without further permission

For information on Institutional Fellowships contact consortiasales@bmjgroup.com

Visit casereports.bmj.com for more articles like this and to become a Fellow 